\title{
Financial Market Pricing of Earnings Quality: Evidence from a Multi-Factor Return Model
}

\author{
Gregory M. Dempster ${ }^{1 *}$, Nathaniel T. Oliver ${ }^{2}$ \\ ${ }^{1}$ Department of Economics and Business, Hampden-Sydney College, Hampden Sydney, VA, USA \\ ${ }^{2}$ Finance Area, IBM Global Business Services, Armonk, NY, USA \\ Email: *Gdempster@hsc.edu
}

How to cite this paper: Dempster, G.M and Oliver, N.T. (2019) Financial Market Pricing of Earnings Quality: Evidence from a Multi-Factor Return Model. Open Journal of Business and Management, 7, 312-329. https://doi.org/10.4236/ojbm.2019.71021

Received: November 13, 2018

Accepted: January 20, 2019

Published: January 23, 2019

Copyright () 2019 by author(s) and Scientific Research Publishing Inc. This work is licensed under the Creative Commons Attribution International License (CC BY 4.0).

http://creativecommons.org/licenses/by/4.0/

\begin{abstract}
Although earnings quality has been an important part of literature in accounting and financial economics for some time, there are relatively few examples of empirical work designed to isolate the effects of variation in earnings quality on the returns to equity ownership in the marketplace. Building on the previous literature, we conduct a robust analysis of these effects by employing earnings restatements as a proxy for quality of earnings in a multi-factor return model. Our results indicate that material misstatements of earnings are priced risk factors that have persistent (long-run) impacts on equity returns. Applications to business practice are discussed in the light of these results.
\end{abstract}

\section{Keywords}

Earnings Quality, Cost of Equity, Financial Markets, Multi-Factor Return Models

\section{Introduction}

Significant manipulations of (or material omissions from) audited financial statements by public corporations can be problematic for investors and other users of a firm's financial reports. Greater attention to the concept of earnings quality, a catch-all term for the reliability of accounting information contained in the financial statements of corporate enterprises, may represent a response to perceptions that the manipulation of financial reporting has increased. There has been relatively little work, however, on market reactions to evidence of earnings manipulation apart from the rather immediate impact of a forced earnings restatement. Specifically, while there has been an abundance of research into the prevalence and indications of earnings management, the long-run impact of variation in earnings quality has been under-explored in the literature. 
Earnings quality refers to the "ability of reported earnings to reflect true earnings, as well as the usefulness of reported earnings to predict future earnings" [1]. Measuring earnings accurately is important because "current earnings are useful for predicting future earnings... [which] are an indicator of future dividend-paying ability" [2]. The accounting concept of earnings quality, thus, is tied directly to the economic interpretation of earnings, or, "the extent to which reported earnings faithfully represent Hicksian income, [including] the change in net economic assets other than from transactions with owners" [3]. As reported by Healy and Whalen (1999), "investors view earnings as value-relevant data" for assessing the prospects of corporate enterprises [4].

Earnings quality can also be a useful indicator of the degree of earnings management, although the two related concepts are not synonymous. Schipper (1989) defines earnings management as the "purposeful intervention in the external reporting process with the intent of obtaining some private gain" ([5], p. 92). The quality of earnings is affected by decisions by standard setters, management choices regarding which accounting methods should be chosen, and judgments and estimates made to implement the chosen alternatives [6]. Earnings management can affect the quality of earnings on each of these dimensions ([6], p. 356). Smoothing patterns for earnings can be used to communicate superior earnings to investors [7] [8], beat analysts' expectations [9], and raise stock prices [10]. Positive relationships are often exhibited between earnings management risk and planned audit hours, billing rates, and corporate governance risk [11]. Earnings management represents an important and, possibly, expensive aspect of managerial behavior that must be monitored by investors and regulators.

As it relates specifically to earnings management, earnings quality is also an ethical issue. As pointed out by Abdelghany (2005), an organization that manages earnings "sends a message to its employees that bending the truth is an acceptable price" and risks "creating an ethical climate in which other questionable activities may occur" ([12], p. 1002). Thus, the relationship between earnings quality and the market pricing of equity claims involves important aspects of economic theory, accounting standard setting, and business ethics.

The current paper develops an econometric model of the impact of earnings quality on measures of market returns, to explore the level of "market monitoring" of earnings quality and management. Evidence from the model suggests that market valuations adjust to perceived indicators of low earning quality by increasing the firm's cost of capital in response to those indicators. In other words, earnings quality is a priced risk factor. This means that perceptions of earnings management will not only damage the firm in the short-run by reducing market equity values, as previously demonstrated, but will also reduce the net present value of future projects in the long-run.

\section{Background Literature}

Much of the literature on earnings quality and earnings management focuses on 
the extent to which earnings management can be detected from publicly-available accounting information. For example, Das, et al. (2009) address whether the pattern of quarterly earnings can potentially serve as an indicator of earnings management [13]. Using quarterly data on COMPUSTAT firms from 1988 to 2004, along with CRSP daily returns on those firms, they compare firms with earnings reversals to a control sample of similar, non-reversal firms (based on seasonal changes in quarterly EPS, before extraordinary items). Their results indicate that reversals are frequent; that significant changes in fourth quarter cash flows and tax rates, relative to industry averages, indicate earnings manipulation rather than mean reversion and other alternative explanations; and that market participants, on average, regard reversals in earnings changes as efforts to manage earnings.

Researchers must take care, however, when utilizing reversals, or restatements, of earnings to determine the existence or extent of earnings management. Hennes, et al., (2008) examine whether the power of hypothesis tests on accounting restatements could be significantly improved by either limiting the restatement sample to verified "irregularities" - actual instances of earnings manipulation-or by including variables that distinguish between irregularities and (unintentional) errors [14]. The impetus for the idea is that expected turnover rates observed in top management in firms that restate earnings are lower than expected; the authors thought this likely a result of the fact that restatements may often be due to errors, and thus not perceived as evidence of manipulation. Generally speaking, only true irregularities might indicate earnings management that is potentially subject to long-run market discipline.

Employing data that includes all 8-K filings between 2002 and 2005, Hennes, et al., identify restatements that correct previous misapplications of GAAP using three sets of criteria. The authors determine that 24 percent of the restatements in the sample period were irregularities and 76 percent were errors. After refining the sample, they employ COMPUSTAT return data and find evidence that firms who announce a restatement attributed to irregularity suffer significant decreases in returns, while firms that restate earnings due to an error have financial returns dip only slightly. Overall, the findings indicate that the effects of earnings restatements due to manipulation are more likely to be persistent than those due to errors in accounting procedure.

Dechow, et al. (2011) address two related questions: What causes managers to misstate their firms' financial statements, and how best can investors, auditors, financial analysts, and regulators detect those misstatements [15]? Their study examines 2190 AAERs from 1982 to 2005 and identifies firms with misstated quarterly and or annual earnings, finding that the misstatement of expenses, the overstatement of revenues, and capitalization costs are the most common forms of misstatement. The study also identifies the time periods and industries in which misstatements were most common. The authors identify the characteristics of misstating firms in the constructed database using a series of variables in- 
cluding accrual quality, financial performance, nonfinancial performance, off-balance-sheet activities, and market related variables.

Some interesting conclusions emerge from the Dechow, et al., study. For example, at the time of a misstatement, accrual quality is generally low and both financial and non-financial measures of performance are deteriorating; financing cash-flow activities, and related off-balance-sheet activities, are much more likely; and, managers of the misstating firms were particularly sensitive to the firm's stock price. The authors construct a composite measure of the likelihood of earnings manipulation, giving researchers a complementary measure to discretionary accruals for identifying low quality earnings. Their work also demonstrates that financial statement information beyond accruals is useful for identifying earnings manipulation.

Intuitively, it makes sense that measures of earnings quality, such as the overuse of accruals or the presence of "Big Bath" charges, should be linked to equity returns, since indications of earning management should be considered a risk factor in forecasting cash flows from holding equities. A unified, formal theory of this effect, however, has still not been firmly established. ${ }^{1}$ Bender and Wilson (2013) explore whether earnings quality should be considered an alpha signal, a true risk factor, or both, concluding from evidence of accrual-based measures that the first of these possibilities has the most support [19]. By contrast, Ecker, et al. (2006), find that treating measures of earnings quality as a risk factor, analogous to market beta and other factor sensitivities, is supported by data on earning restatements, class action lawsuits relating to earnings, and bankruptcies [20].

Further empirical work has continued to explore the relationship between earnings quality and returns, generally indicating that a relationship does exist. What has not been adequately determined, however, is the extent to which this relationship is primarily transitory, (i.e., an alpha signal), persistent, (i.e., a priced factor) or a combination of both [21] [22] [23]. While research has firmly tied earnings restatements to losses in market value [24] [25], comparatively little work has examined the extent to which restatements affect discount rates and the cost of capital by increasing perceptions of risk. Hribar and Jenkins (2004) are among the few to examine the direct impact of restatements on the implied cost of capital, finding that the latter increases by $7 \%$ - 19\% in month following a restatement, and that the effect continues to be positive, though perhaps declining, in the longer run [26]. Francis, et al. (2004), examine the relation between cost of capital and several attributes of earnings quality, including accrual quality, persistence, predictability, and smoothness [17]. These studies represent attempts to measure direct impacts on the cost of capital, rather than relying on indirect evidence indicated by proxies for disclosure level and cost of capital [27] ${ }^{1}$ See, e.g., Easley and O’Hara (2005), Francis, et al. (2004), and Lambert, et al. (2007), for examples of work relating to the treatment of earnings quality as a priced risk factor [16] [17] [18]. Thomas and Zhang (2002) also explore the theoretical relationship between earnings quality and future returns [8]. 
[28]. Our research is an attempt to better illuminate these impacts by allowing for both transitory and persistent (priced) impacts on market behavior, thus distinguishing between the earnings and risk adjustment impacts of earnings restatements.

\section{Measures of Earnings Quality in Asset Pricing Models ${ }^{2}$}

Previous research suggests a firm's earnings quality should have implications for the pricing of risks in the marketplace [17] [26]. Our attempt to determine the impact of earnings management on financial returns, thus, requires that we estimate the level of earnings quality on a firm-by-firm basis. There are two types of earnings quality measurements in the literature: Input-based measures taken from data about financial disclosures themselves, and output-based measures that track the expected consequences of earnings management for important financial time series. Input measures of earnings quality employ information about managerial decisions for a specific firm as reflected in the accounting statements that they publish. Some examples of input measures include the net levels of (or changes in) accrual and deferred accounts, the ratio of net operating assets to sales, and the frequency of "Big Bath" charges.

One of the more widely used input measures involves the behavior of accruals [24] [27] [29] [30]. DeAngelo (1986) tests for earnings management by computing first differences in a firm's total accruals over time, under the assumption that these first differences have an expected value of zero under the null hypothesis of no earnings management [31]. Healy and Whalen (1999) report that investors discount "abnormal" accruals relative to "normal" accruals, indicating that they view abnormal accruals as more likely to reflect earnings management. Other input measures focus on the accumulation effects that earnings management would be expected to produce [4]. Barton and Simko (2002) predict that, since the balance sheet accumulates the effects of previous accounting choices, the level of net operating assets relative to sales partly reflects the extent of previous earnings management (the "earnings surprise" indicator) [32]. Abdelghany (2005) posits that earnings are managed by overstating one-time "Big Bath" charges and then reversing the excessive reserve so that future earnings will increase [12].

Output measures of earnings quality focus on the ultimate results of published earnings over time, and on the relationships between those earnings and the financial fundamentals they represent. Schipper and Vincent's (2003) review of the earnings management literature suggests three important time-series constructs associated with these output measures: persistence, predictability, and variability [3]. Persistence refers to the sustainability of earnings effects on stock prices; i.e. the extent to which a change in the level of earnings translates into a "permanent" change in stock price. Predictability refers to the ability to use cur${ }^{2}$ Dechow, et al. (2011), provide a comprehensive overview of issues relating to earnings quality measurement [15]. Much of the discussion in this section is derived from that paper and Dempster (2008) [33]. 
rent earnings to forecast future earnings. Variability refers to the extent to which volatility in earnings reflects volatility in the underlying fundamentals of the firm, such as the free cash flow generation. Each of these constructs is employed to various degrees in the earnings management literature. For example, Penman (2001, 2003) employs the notions of predictability and variability in measuring the quality of earnings by the ratio of cash flow from operations (CFO) to net income [34] [35]. To the extent that earnings are reliable indicators of the firm's ability to generate current and future cash flows, a smaller ratio indicates a higher quality of earnings. On the other hand, extensive use of accruals to manage earnings would show up as a consistent divergence between CFO and net income. In a similar vein, Leuz et al. (2003) suggest that the quality of earnings is measured by the relative variability of earnings, which is equal to the standard deviation of operating income divided by the standard deviation of cash flow from operations [36]. The smaller the ratio, the lower the quality of earnings, on the logic that "true" earnings reflect the generation of current and future cash flows.

Another output measure is the number and/or magnitude of earnings restatements. As mentioned previously, earnings restatements can be the result of either accounting errors, which should be essentially random, or accounting irregularities, which could reflect attempts to manage earnings. Moriarty and $\mathrm{Li}$ vingston (2001) report that there were 1080 earnings restatements by U.S. public companies from 1977 to 2000 [37], and Magrath and Weld (2002) indicate that improper revenue recognition practices were the cause of one-third of all voluntary or forced restatements of income filed with the SEC over this period [38]. To the extent that these restatements induce market reactions, they can potentially be employed as indicators of previously-inaccurate earnings reporting subject to both short-term (transitory) and long-term (persistent) adjustments in equity prices and returns.

\section{Multi-Factor Models and their Application to Earnings Quality}

Multi-factor return models are best known in the context of financial economics, where they are routinely used to predict and measure the required returns on portfolios of financial assets as a function of priced risk factors, which are indexes thought to be related to the risks that are relevant for pricing the portfolios. For example, a simple and well-known multi-factor model of required returns is the Fama and French (1993) three-factor model [39]. The Fama-French model suggests that the relevant risks for financial asset pricing are summarized in three indexes: One that measures the non-diversifiable market-related risk of the asset, another that adjusts the risk premium for firm size (a size premium), and a third that adjusts the risk premium for the ratio of market value to book value (a value premium). The rationale for such a model is that financial market participants will systematically require greater returns from riskier portfolios of assets. Importantly, we employ this model not only because of its demonstrated 
value in predicting long-run returns, but also because it incorporates measures of firm size and profitability, both of which have been connected to incentives for earnings management [40] and, therefore, must be controlled for in a study of earnings quality impacts on financial returns. ${ }^{3}$

The Fama-French three-factor model of asset returns can be expressed in a regression equation as,

$$
R_{t}-R_{r f}=a+b_{1} \beta+b_{2} S+b_{3} V+e_{t}
$$

where $R_{t}$ is the one-period return on the asset in period $t, R_{r f}$ is the risk-free rate, $\beta$ is the market beta of the asset (defined as the sensitivity of the asset's returns to those on the market portfolio), $S$ is the size of the firm measured in market capitalization, $V$ is the relative value of the firm measured by the book-to-market ratio, and $e_{t}$ is an idiosyncratic error term in time $t$. To derive factor sensitivities, $b_{i p}$ historical data on the asset returns are regressed on measures of the relevant factors using a method such as ordinary least squares. The estimated coefficients on the factors represent the factor sensitivities. These can then be used to predict the returns required on portfolios constructed of assets with measurable factor exposures. To the extent the model holds true, the required return can be thought of as a long-run prediction of tendencies in portfolio returns, and can therefore be used to determine over- or under-valuation of portfolios based on their current market prices.

The approach in this paper is to take this method which is common to financial analysis and apply it to the problem of earnings quality monitoring. There are two possible linkages between earnings quality and a firm's market returns in our model. First, to the extent that market participants recognize earnings quality as a long-run risk factor that should be systematically discounted, firms with relatively low earnings quality will pay higher systematic returns relative to the risk-free rate. This interpretation of earnings quality discounting rests on the idea that earnings management is likely to be negatively correlated with true, underlying firm performance, and thus cyclical in its impact upon the variance in the firm's portfolio value; i.e., it is likely that the distorting effects of earnings manipulation will be most prominent during times when performance is poor and earnings management is potentially most profitable. In this scenario, earnings quality becomes a systematic discount factor and will be assessed as part of the firm's overall risk profile. A second possibility is that earnings quality is assessed on a period-by-period basis and, in effect, marked-to-market as part of the asset pricing process. In this alternate scenario, long-run returns remain determined only by stable risk factors, but short-run periodic returns vary with respect to the market's evaluation of earnings quality on an idiosyncratic (firm-by-firm) basis. This second scenario avoids strong claims about the nature of long-run asset pricing and merely asks whether periodic returns appear sensitive to ${ }^{3}$ An alternative would have been to employ something like the five-factor Fama-French (2015) model that explicitly includes profitability [41]. However, since our econometric design incorporates book value as an independent variable, additions to asset value via profitability are accounted for as directly as is necessary for our purposes. 
changes in the level of earnings quality.

We focus on an econometric design that incorporates both interpretations. The systematic discounting of earnings of low quality should provide the strongest evidence that markets select among equity offerings based on quantitative and/or qualitative assessments of earnings risk. We note, however, that there is already considerable evidence of the weaker linkage in the literature [25]. Our attempt can be viewed as an extension of this framework to the long-term impacts of earnings management on asset returns which, according to financial theory, should be displayed in increased required returns to a firm's equities where systematic evidence of earnings management and/or low earnings quality is present.

\section{Data and Methods}

Twenty years of data on annual returns for S \& P 500 stocks in the period December 1995-December 2014 from were obtained from Mergent Online. We designate the average value of these returns over the period as our dependent variable (RETURN) to explore the impact of earnings quality on the long-run return to $S$ \& P 500 stocks. Observations without complete returns for the period are dropped from the sample. Following a common technique illustrated by Barnett and Salomon (2006), we decompose the return into its systematic and idiosyncratic components [42],

$$
R_{i}=a+b X_{i}+u_{i}
$$

where $R_{i}$ is the average annual return to firm $i, X_{i}$ is the vector of independent variables that determine returns to the firm, and $u_{i}$ is an idiosyncratic error term. Our control variables include the period averages for the firm's 10-year (2005-14) equity beta (BETA), size in terms of market capitalization (MARKET CAP), book value per share (BVPS), and the number of shares outstanding (SHARES $\mathrm{O} / \mathrm{S}$ ), as suggested by the Fama-French three-factor model. ${ }^{4}$ We also employ the firm's average price-earnings ratio $(\mathrm{P} / \mathrm{E})$ as an alternative measure for capturing the growth and value components of the Fama-French model. All data for our controls is acquired from the Mergent Online database. Descriptive statistics are presented in Table 1 . The mean values indicate that returns averaged around $20.5 \%$ per annum for S \& P equities, average beta was 1.167, and just under $23 \%$ of firms had at least one earnings restatement during the period. Missing data were dropped from the sample, so that only observations with complete data for all control variables was employed. ${ }^{5}$

Our primary interest is in using these data to uncover the impact of earnings quality assessments on the risk premium required on equities. To measure earnings quality, we employ the Government Accounting Office (GAO) dataset

${ }^{4}$ Multiplying Shares Outstanding and BVPS converts the two independent terms into the numerator of the value term of the Fama-French model. The denominator, market capitalization, is already included in the equation. We employ this decomposition to ensure that both firm size and profitability are independently controlled for in the model.

${ }^{5}$ Observations with missing $\mathrm{P} / \mathrm{E}$ data were only dropped for the relevant equations. 
Table 1. Descriptive Statistics for S \& P 500 Equities, 1995-2014. Source: Mergent Online.

\begin{tabular}{ccccc}
\hline Variable & Mean & Median & Std. Dev. & Valid Obs. \\
\hline RETURN & 0.205 & 0.154 & 0.229 & 491 \\
BETA & 1.167 & 1.051 & 0.936 & 477 \\
RESTATEMENT & 0.229 & 0.000 & 0.420 & 494 \\
MARKET CAP & $\$ 215$ million & $\$ 8.1$ million & $\$ 1.4$ billion & 486 \\
BVPS & $\$ 16.90$ & $\$ 12.11$ & $\$ 28.22$ & 492 \\
SHARES O/S & 6.72 million & 244,027 & 44.1 million & 493 \\
P/E & 31.29 & 19.58 & 78.21 & 440 \\
\hline
\end{tabular}

of financial restatement announcements to determine whether a restatement occurred for the firm over the period 1995-2014. RESTATEMENT is a binomialvariable equal to either one or zero, depending on whether a restatement is recorded for the period. We make no attempt to parse the data into "irregularities" and "errors" in the manner suggested by Hennes, et al. (2008); thus, our measure of earnings quality does not speak to earnings management or intentional manipulation directly. Instead, we rely on the design of the empirical model to produce differential effects that might be indicative of distinctions between transitory and persistent impacts dictated by market behavior.

Financial theory suggests that, for cases where earnings are thought to have been actively manipulated, there should be a persistent effect on the risk premium applied to equity returns; evidence of earnings manipulation should result in a systematic increase in the minimum return required on equity financing subject to this risk. If this is the case, then restatement events can be employed as a proxy for non-diversifiable risks that would permanently increase equity risk premia for firms where the restatements reflect "irregularities" as opposed to "errors" [14]. Therefore, we extend Equation (2) above to include an interactive term that relates restatements to increases in non-diversifiable risk:

$$
R_{i}=a+b X_{i}+c \text { RESTATEMENT } \times \text { BETA }_{i}+u_{i}
$$

where $c$ is the coefficient on the interactive term between our earnings quality measure (RESTATEMENT) and firm-specific, non-diversifiable risk (BETA). This interaction implies that earnings quality is a priced risk factor that makes a firm's returns more variable with respect to the market and, thus, systematic in nature. A positive sign for $c$ would indicate a re-evaluation of systematic risk for the equity whose earnings have been subject to perceived manipulation. We note that, in the absence of a risk-free rate among the independent variables, the risk-free return $\left(R_{r f}\right)$ will be unidentified and, thus, incorporated into the constant, $a$; the constant term is not, therefore, analogous to a measure of alpha $(\alpha)$ or excess systematic return.

The above specification only accounts for increases in systematic (i.e. priced) risk-adjustments to returns that occur as investors learn that past earnings have been misleading. However, as mentioned earlier, there is theory and evidence 
that certain types of restatements, i.e., those resulting from errors rather than irregularities, are likely to have only transitory effects on returns; and, while these restatements due to an unintentional accounting error may be problematic, their effects are confined to a one-time adjustment in present values. Since this is a possibility, our model should be amended to reflect these transitory effects on return.

We accomplish this by including our earnings quality proxy as a separate independent variable that does not interact with market risk. Modifying Equation (3) with the addition of our non-interacted measure yields,

$$
R_{i}=a+b X_{i}+c \text { RESTATEMENT } \times \text { BETA }_{i}+d \text { RESTATEMENT }_{i}+u_{i} \text { (4) }
$$

Thus, our empirical design allows for a distinction between transitory shocks due to accounting errors or unintentional omissions, and persistent shocks due to irregularities that indicate evidence of aggressive accounting and earnings manipulation. One would expect market participants to systematically discount the equities of companies that appear to engage in the latter, while not for the former. Our expectations are that the coefficient estimate for $d$ should be negative, indicating one-time downward adjustments due to new information about earnings, while the estimate for $c$ should be positive, as an indication of permanent discounting. Essentially, our two coefficients $c$ and $d$ represent impacts on beta (risk) and alpha (unsystematic return), respectively.

Finally, there is some concern about the use of the standard Fama-French factors on a data set that consists essentially of only large firms with considerable market and book values. The Fama-French size and value terms are meant to be measured relative to a set of complete portfolio options, and do not necessarily apply in a large firm setting. Due to the extensive evidence of both "value" and "growth" premia across equity markets, we can employ the firm's average price-earnings (P/E) ratio over the sample period as an alternative indicator of these premia. Our regression estimates, therefore, include two versions of Equation (3) and Equation (4), one with the standard Fama-French measures for size and value, and one with $\mathrm{P} / \mathrm{E}$ as a single indicator of value and growth impacts on long-run returns.

\section{Results and Interpretation}

The regression results are presented in Table 2. Pooled Ordinary Least Squares with unadjusted standard errors is used to estimate the parameters $a, b, c$, and $d$. Standard errors and t-statistics are presented for ease of interpretation. Among the control variables, only market beta (BETA) shows a statistically significant, positive effect. This suggests that a simpler model like CAPM may be appropriate for measuring required returns to S \& P 500 stocks. F-statistics and log likelihood ratios suggest significance for the overall regression at well within the standard 5\% probability level.

We begin with our equation for the basic Fama-French model with an interaction term for increases in perceived risk. Our variable of interest, the 
Table 2. Pooled OLS Results for Earnings Quality Impact on Average Annual Returns to S \& P 500 Equities, 1995-2014. Unadjusted standard errors.

\begin{tabular}{ccccc}
\hline Variable & Coef. (S. E.) & Coef. (S. E. $)$ & Coef. (S. E.) & Coef. (S. E.) \\
\hline CONSTANT & $0.074(0.024)^{* *}$ & $0.089(0.028)^{* *}$ & $0.054(0.024)^{* *}$ & $0.069(0.028)^{* *}$ \\
BETA & $0.101(0.020)^{\star *}$ & $0.089(0.022)^{* *}$ & $0.093(0.021)^{* *}$ & $0.083(0.023)^{* \star}$ \\
MARKET CAP & $2.52 \mathrm{e}^{-11}\left(1.2 \mathrm{e}^{-11}\right)$ & $1.53 \mathrm{e}^{-11}\left(1.2 \mathrm{e}^{-11}\right)$ & & \\
BVPS $\times$ SHARES O/S & $-7.06 \mathrm{e}^{-11}\left(4.5 \mathrm{e}^{-11}\right)$ & $-2.84 \mathrm{e}^{-11}\left(4.5 \mathrm{e}^{-11}\right)$ & & \\
P/E & & & $0.001(0.0001)^{* *}$ & $0.001(0.0001)^{* *}$ \\
RESTATEMENT $\times$ BETA & $0.038(0.019)^{* *}$ & $0.087(0.047)^{*}$ & $0.053(0.019)^{* *}$ & $0.099(0.048)^{* *}$ \\
RESTATMENT & & $-0.065(0.057)$ & & $-0.060(0.057)$ \\
R-squared & 0.0758 & 0.0783 & 0.1762 & 0.1784 \\
Adj. R-squared & 0.0678 & 0.0683 & 0.1703 & 0.1705 \\
Mean of dep. variable & 0.1987 & 0.1987 & 0.1963 & 0.1963 \\
Observations & 467 & 467 & 423 & 423 \\
\hline
\end{tabular}

*, ** indicate significance at the $10 \%$ and $5 \%$ levels, respectively.

risk-assessment effect of restatements, shows a significant positive impact on the average annual return to S \& P 500 stocks, in accordance with expectations. The coefficient on the interactive term, RESTATEMENT $\times$ BETA, is large, positive, and statistically significant, suggesting that, to the extent that investors consider restatements an indicator of earnings manipulation, investors adjust their long-term required returns on the affected equities. According to these results, an instance of restatement causes an increase in required return of 3.8\% for each measured unit of beta. To illustrate the impact, consider a stock with average risk $(\mathrm{BETA}=1)$ that is subject to a restatement of earnings. Ignoring the minimal impact of the Fama-French coefficients for market cap, book value per share, and number of shares, the stock's predicted required return from the model would be about $r^{\star}=0.074+0.101+0.038=0.213$, which represents a $37.6 \%$ increase in the risk premium and a $21.7 \%$ increase in required return compared to an equity with no instance of restatement.

Of course, our theoretical discussion suggests that this is an average over all instances of restatements, including those that are judged as errors as well as irregularities. The average is, thus, being generated only by the subset of restatements that indicate irregularities which, according to Hennes et al., comprise only about a quarter of all restatements. The second estimated equation can provide a more accurate illustration by including both the transitory effect of revaluation of earnings (alpha) and the persistent effect on perceived risk (beta). The coefficient on the binomial RESTATEMENT variable represents an immediate, one-time revaluation of the equity based on a new set of expected cash flows. Although not a statistically-significant estimate, the coefficient is negative as expected, indicating a sudden decrease of about $6.5 \%$ of an equity's market value, caused by adjustments to new expectations concerning the values of future cash 
flows.

The results of our second estimation of the variable of interest are more telling than those of the first. The coefficient on the interactive term is more than double that of the first estimation without the transitory alpha term included. Given that only a fraction of restatements indicate accounting irregularities, this is to be expected. Recall that while every restatement is subject to a one-time readjustment of return based on revaluation, regardless of the cause of the restatement, each restatement has only about a 1-in-4 chance of necessitating an increase in required return due to an irregularity. Assuming the 3-to-1 ratio of errors to irregularities holds, the second equation is likely to provide a much better estimate for long-term reactions for earnings manipulation in cases where actors see evidence of its occurrence. The results suggest an additional $8.7 \%$ of required return on an average-risk equity subject to an earnings restatement due to accounting irregularities.

Owing to the aforementioned issues with the value and growth premiums employed in Equation (3), we also perform a set of estimations substituting the average P/E ratio for the standard Fama-French size and book value terms. The results of these alternative estimations are very much in line with the previous results. Parameter estimates for the upward risk-premium adjustment range from $5.3 \%$ to $9.9 \%$ for an average-risk stock, while the estimate for the one-time adjustment indicates a decrease of $6.0 \%$. Interestingly, although we lose some observations because of missing $\mathrm{P} / \mathrm{E}$ data, the goodness of fit increases with these models, and the parameter estimate for $\mathrm{P} / \mathrm{E}$ is positive and statistically significant, though small in magnitude.

Our results from these regressions indicate two possible effects on the returns of equities subject to an earnings restatement: A transitory decrease in the expected value (market price) of the stock based on revaluations of the cash flows expected from holding the equity claim, and a long-term increase in the equity cost of capital due to a reassessment of the risk associated with earnings estimates based on the firm's financial reports. We reason that the first of these effects has little to do with earnings manipulation, but that the second is solid evidence that investors incorporate evidence of earnings manipulation into their assessments of financial risks associated with holding equities. Based on our estimations, the effect of perceived manipulation on an equity with average market risk is between $3.8 \%$ and $9.9 \%$, with models that include a transitory impact on equity alpha yielding much higher risk-adjustment impacts than those without.

Care must be taken in interpreting the coefficient estimates; we have employed a limited data set and failed to control for numerous firm-level effects that might influence long-run returns. These results, however, provide reasonable support to conclusions already explored in the literature. Our estimates for the unadjusted market risk premium range from $8.9 \%$ to $10.1 \%$, well within the range of normal estimates. Our estimates of the transitory impact of earnings restatements also fit well within established estimates. For example, Palmrose, et 
al. (2004) suggest that the periodic "penalty" on firms that restate earnings is in the range of $6 \%-20 \%$ of the firm's beginning equity value [25]. Since these control parameters appear reasonable, our estimates provide a solid basis for exploring further long-run implications of earnings quality on the market pricing and required returns of equity offerings.

To add robustness to the results, we employed some alternative specifications that could address unobserved statistical issues. Pooled OLS with White heteroskedasticity-consistent standard errors should produce similar coefficient estimates with reduced statistical significance. Low statistical significance and magnitudes on our controls for market capitalization (MKT CAP) and book value (BVPS times SHARES O/S) suggest that these variables might be better employed as instruments to control for omitted variable bias in the form of endogeneity between our independent variables and average annual returns, rather than as independent controls. Finally, the actual number of restatements (RESTATE NUM) could be used as an alternate proxy for the transitory (short-run) effects of accounting "errors" that lead to restatements, although it would be inappropriate as a long-run indicator of earnings quality. ${ }^{6}$ Results presented in Table 3 below are derived from these alternate specifications, using P/E as the proxy for Fama-French growth and value premia. Regression results are obtained employing (1) a pooled least squares version with White-adjusted error terms and (2) two-stage least squares using the Fama-French variables as instruments. Each of the two sets includes one model where the transitory effect of restatements (RESTATE NUM) is excluded and one with it included. Unsurprisingly, significance levels fall for earnings quality in the case of the pooled OLS model with corrected errors, meaning that the OLS model might be particularly sensitive to heteroskedasticity. The 2SLS model, on the other hand, exhibits roughly the same signs and significance levels as our previous models; probability levels for our variable of interest remain in the standard ranges for statistical relevance. Therefore, we are confident that our results are at least somewhat robust to alternative methodologies for estimating the impact of restatements on expected returns.

Our results suggest that perceptions of earnings quality are an important component of risk differentiation among S \& P 500 equities. In fact, although much of the systematic variation in equity returns that we would normally ascribe to market risk (BETA) is captured by that term alone, interaction with restatement activity contributes an additional impact of anywhere from 380 to 990 basis points of required return on an average-risk stock, with most estimates near the mid-range (500 - 550) of the spectrum. Reasonable efforts to account for endogeneity do not alter these relationships much. Most importantly, the results confirm our priors by indicating a distinct impact of restatement activity on long-run returns apart from the transitory effect that lowers (penalizes) the ${ }^{6}$ This is because, although each instance of restatement may require a separate re-evaluation of cash flows, evidence of manipulation is actually a characteristic of the firm, not the restatement instance itself, so that the same behavior (earnings management) can produce multiple instances of restatements over time. 
Table 3. Pooled OLS (White-adjusted standard errors) and Two-Stage Least Squares Results for Earnings Quality Impact on Average Annual Returns to S \& P 500 Equities, 1995-2014.

\begin{tabular}{ccccc}
\hline & Pooled OLS & Pooled OLS & 2SLS & 2SLS \\
\hline Variable & Coef. (S. E.) & Coef. (S. E.) & Coef. (S. E.) & Coef. (S. E.) \\
\hline CONSTANT & $0.054(0.033)^{*}$ & $0.059(0.032)^{*}$ & $0.054(0.025)^{* *}$ & $0.059(0.025)^{* *}$ \\
BETA & $0.093(0.016)^{* *}$ & $0.094(0.016)^{* *}$ & $0.094(0.021)^{* *}$ & $0.095(0.021)^{* *}$ \\
P/E & $0.001(0.001)$ & $0.0001(0.0001)$ & $0.001(0.0001)^{* *}$ & $0.001(0.0001)^{* *}$ \\
RESTATEMENT $\times$ BETA & $0.053(0.043)$ & $0.052(0.043)$ & $0.051(0.020)^{* *}$ & $0.051(0.020)^{* *}$ \\
RESTATE NUM & & $-0.017(0.007)^{* *}$ & & $-0.017(0.012)$ \\
R-squared & 0.1762 & 0.1800 & 0.1727 & 0.1765 \\
Adj. R-squared & 0.1703 & 0.1722 & 0.1667 & 0.1686 \\
Mean of dep. variable & 0.1963 & 0.1963 & 0.1954 & 0.1954 \\
Observations & 423 & 423 & 419 & 419 \\
\hline
\end{tabular}

*, ** indicate significance at the $10 \%$ and $5 \%$ levels, respectively.

firm's market value-an interactive impact with market beta that increases the minimum required long-run return on the equity. We interpret this to indicate evidence of a systematic discounting of prices on equities where accounting irregularities suggest the presence of aggressive accounting and/or earnings manipulation.

\section{Conclusions}

We have conducted a series of empirical tests of the relationship between accounting restatements and long-run returns to S \& P 500 stocks. The results strongly support our hypothesis that long-run returns are sensitive to perceptions of earnings manipulation as indicated by earnings restatements. However, limitations inherent in this study suggest avenues for further development.

First, a larger sample of equities from the NYSE, NASDAQ, or other (including non-U.S.) exchanges would allow for additional controls as well as fixed and/or random effect models. Additional input and output measures of earnings quality could also provide useful variation and give a better idea of how markets do and do not interpret firm level data on earnings quality assessments. Best of all would be the use of comprehensive indexes of earnings quality, as illustrated in Dempster (2008).

We have utilized a simple measure of long-run returns as our dependent variable: average annual returns based on a 20 -year time series. Alternative approaches to measuring the long-run impacts of earnings quality would include employing actual monthly returns in a panel data set, producing required returns from a more complex model like Arbitrage Pricing Theory (APT), or foregoing return data altogether and opting instead for price-driven data like Price/Earnings, Price/Cash Flow, EV/EBITDA or other multiples. Rates of discount from market 
or industry norms could be examined in this context as possible indications of market assessment of earnings quality. Finally, adding firm and industry level controls, as well as parsing "irregularities" from "errors" in accounting restatements, could add explanatory power to our generalized format. We believe, nonetheless, that the research contained herein represents an important step toward a better understanding of earnings quality assessment in financial markets.

If confirmed by further research, our findings have important practical implications, particularly for managers of publicly traded companies. Others have investigated the importance of financial sector transparency in promoting market stability [43] [44] [45]. Market monitoring of earnings quality enhances financial sector transparency by providing an independent mechanism for assessing the risks associated with reliance on financial reporting. The confirmation of market monitoring of these risks should be of interest to managers concerned with the impacts of earnings quality on long-run equity returns. Our findings suggest that firms engaging in earnings management can suffer significant increases in their cost of capital, thus enhancing the value of prudent controls on internal accounting procedures.

\section{Acknowledgements}

The authors would like to thank Megan Hess, Jared Harris, and other members of the Darden doctoral program's Spring 2011 Seminar in Corporate Governance for many helpful suggestions and comments. This work was partially funded by the Citrone Student-Faculty Fellowship program at Hampden-Sydney College.

\section{Conflicts of Interest}

The authors declare no conflicts of interest regarding the publication of this paper.

\section{References}

[1] Bellovary, J.L., Giacomino, D.E. and Akers, M.D. (2005) Earnings Quality: It's Time to Measure and Report. The CPA Journal, 75, 32-37.

[2] Bauman, M.P. (1996) A Review of Fundamental Analysis Research in Accounting. Journal of Accounting Literature, 15, 1-33.

[3] Schipper, K. and Vincent, L. (2003) Earnings Quality. Accounting Horizons, 17, 97-110. https://doi.org/10.2308/acch.2003.17.s-1.97

[4] Healy, P.M. and Whalen, J.M. (1999) A Review of the Earnings Management Literature and Its Implications for Standard Setting. Accounting Horizons, 13, 365-383. https://doi.org/10.2308/acch.1999.13.4.365

[5] Schipper, K. (1989) Commentary on Earnings Management. Accounting Horizons, 3, 91-102.

[6] Teets, W.R. (2002) Quality of Earnings: An Introduction to the Issues in Accounting Education. Issues in Accounting Education (Special Issue), 17, 355-360. https://doi.org/10.2308/iace.2002.17.4.335 
[7] Tan, H. and Jamal, K. (2006) Effect of Accounting Discretion on Ability of Managers to Smooth Earnings. Journal of Accounting and Public Policy, 5, 554-573. https://doi.org/10.1016/j.jaccpubpol.2006.07.007

[8] Thomas, J.K. and Zhang, H. (2002) Inventory Changes and Future Returns. Review of Accounting Studies, 7, 163-187. https://doi.org/10.1023/A:1020221918065

[9] Fields, M. and Keys, P. (2003) The Emergence of Corporate Governance from Wall St. to Main St.: Outside Directors, Board Diversity, Earnings Management, and Managerial Incentives to Bear Risk. The Financial Review, 38, 1-24. https://doi.org/10.1111/1540-6288.00032

[10] Barth, M., Elliott, J. and Finn, M. (1999) Market Rewards Associated with Patterns of Increasing Earnings. Journal of Accounting Research, 37, 387-413. https://doi.org/10.2307/2491414

[11] Bedard, J. and Johnstone, K. (2004) Earnings Manipulation Risk, Corporate Governance Risk, and Auditors' Planning and Pricing Decisions. The Accounting Review, 79, 277-304. https://doi.org/10.2308/accr.2004.79.2.277

[12] Abdelghany, K. (2005) Measuring the Quality of Earnings. Managerial Auditing Journal, 20, 1001-1015. https://doi.org/10.1108/02686900510625334

[13] Das, S., Shroff, P.K. and Zhang, H. (2009) Quarterly Earnings Patterns and Earnings Management. Contemporary Accounting Research, 26, 797-831. https://doi.org/10.1506/car.26.3.7

[14] Hennes, K., Leone, A. and Miller, B. (2008) The Importance of Distinguishing Errors From Irregularities in Restatement Research: The Case of Restatements and CEO/CFO Turnover. The Accounting Review, 83, 1487-1519. https://doi.org/10.2308/accr.2008.83.6.1487

[15] Dechow, P., Ge, W., Larson, C. and Sloan, R. (2011) Predicting Material Accounting Misstatements. Contemporary Accounting Research, 28, 17-82. https://doi.org/10.1111/j.1911-3846.2010.01041.x

[16] Easley, D. and O'Hara, M. (2004) Information and the Cost of Capital. Journal of Finance, 59, 1553-1583. https://doi.org/10.1111/j.1540-6261.2004.00672.x

[17] Francis, J., LaFond, R., Olsson, P. and Schipper, K. (2004) Cost of Capital and Earnings Attributes. The Accounting Review, 79, 967-1010. https://doi.org/10.2308/accr.2004.79.4.967

[18] Lambert, R., Leuz, C. and Verrecchia, R. (2007) Accounting Information, Disclosure, and the Cost of Capital. Journal of Accounting Research, 45, 385-420. https://doi.org/10.1111/j.1475-679X.2007.00238.x

[19] Bender, J. and Nielsen, F. (2013) Earnings Quality Revisited. https://ssrn.com/abstract=2543996

[20] Ecker, F., Francis, J., Kim, I., Olsson, P. and Schipper, K. (2006) A Returns-Based Representation of Earnings Quality. The Accounting Review, 81, 749-780. https://doi.org/10.2308/accr.2006.81.4.749

[21] Chan, L., Chen, K., Chen, T. and Yu, Y. (2015) Substitution between Real and Accruals-Based Earnings Management after Voluntary Adoption of Compensation Clawback Provisions. The Accounting Review, 90, 147-174. https://doi.org/10.2308/accr-50862

[22] Perotti, P. and Wagenhofer, A. (2014) Earnings Quality Measures and Excess Returns. Journal of Business Finance and Accounting, 41, 545-571. https://doi.org/10.1111/jbfa.12071

[23] Mitra, R. (2016) The Association between Earnings Quality and Firm-Specific Re- 
turn Volatility: Evidence from Japan. Review of Accounting and Finance, 15, 294-316. https://doi.org/10.1108/RAF-08-2015-0100

[24] Dechow, P., Sloan, R. and Sweeney, A. (1995) Detecting Earnings Management. The Accounting Review, 70, 193-225.

[25] Palmrose, Z., Richardson, V. and Scholz, S. (2004) Determinants of Market Reactions to Restatement Announcements. Journal of Accounting and Economics, 37, 59-89. https://doi.org/10.1016/j.jacceco.2003.06.003

[26] Hribar, P. and Jenkins, N. (2004) The Effect of Accounting Restatements on Earnings Revisions and the Estimated Cost of Capital. Review of Accounting Studies, 9, 337-356. https://doi.org/10.1023/B:RAST.0000028194.11371.42

[27] Healy, P. (1985) The Effect of Bonus Schemes on Accounting Decisions. Journal of Accounting and Economics, 7, 85-107. https://doi.org/10.1145/320435

[28] Botosan, C. and Plumlee, M. (2002) A Re-Examination of Disclosure Level and the Expected Cost of Equity Capital. Journal of Accounting Research, 40, 21-40. https://doi.org/10.1111/1475-679X.00037

[29] Dechow, P. (1994) Accounting Earnings and Cash Flows as Measures of Firm Performance: The Role of Accounting Accruals. Journal of Accounting and Economics, 18, 3-42. https://doi.org/10.1016/0165-4101(94)90016-7

[30] Jones, J. (1991) Earnings Management during Import Relief Investigations. Journal of Accounting Research, 29, 193-228. https://doi.org/10.2307/2491047

[31] DeAngelo, L. (1986) Accounting Numbers as Market Valuation Substitutes: A Study of Management Buyouts of Public Stockholders. The Accounting Review, 40, 400-420.

[32] Barton, J. and Simko, P.J. (2002) The Balance Sheet as an Earnings Management Constraint. The Accounting Review, 80, 1-27. https://doi.org/10.2308/accr.2002.77.s-1.1

[33] Dempster, G. (2008) Determining Earnings Quality: A Multi-Factor Model Approach. Journal of the Academy of Business and Economics, 8, 152-156.

[34] Penman, S. (2001) Financial Statement Analysis and Security Valuation. McGraw-Hill/Irwin, New York.

[35] Penman, S. (2003) The Quality of Financial Statements: Perspectives from the Recent Stock Market Bubble. Accounting Horizons, 17, 77-96. https://doi.org/10.2308/acch.2003.17.s-1.77

[36] Leuz, C., Nanda, D. and Wysocki, P. (2003) Earnings Management and Investor Protection: AnInternational Comparison. Journal of Financial Economics, 69, 505-527. https://doi.org/10.1016/S0304-405X(03)00121-1

[37] Moriarty, G.B. and Livingston, P.B. (2001) Quantitative Measures of the Quality of Financial Reporting; statistical Data Included. Financial Executive, 17, 53.

[38] Magrath, L. and Weld, L.G. (2002) Abusive Earnings Management and Early Warnings Signs. The CPA Journal, 72, 50-55.

[39] Fama, E. and French, K. (1993) Common Risk Factors in the Returns on Stocks and Bonds. Journal of Financial Economics, 33, 3-56. https://doi.org/10.1016/0304-405X(93)90023-5

[40] Truman, B. and Titman, S. (1988) An Explanation for Accounting Income Smoothing. Journal of Accounting Research, 26, 127-139.

https://doi.org/10.2307/2491184

[41] Fama, E. and French, K. (2015) A Five Factor Asset Pricing Model. Journal of Financial Economics, 116, 1-22. https://doi.org/10.1016/j.jfineco.2014.10.010 
[42] Barnett, M. and Salomon, R. (2006) Beyond Dichotomy: The Curvilinear Relationship between Social Responsibility and Financial Performance. Strategic Management Journal, 27, 1101-1122. https://doi.org/10.1002/smj.557

[43] Bushman, R. and Smith, A. (2003) Transparency, Financial Accounting Information, and Corporate Governance. Economic Policy Review, 9, 65-87. https://ssrn.com/abstract $=795547$

[44] Kaufmann, C. and Weber, R. (2010) The Role of Transparency in Financial Regulation. Journal of International Economic Law, 13, 779-797. https://doi.org/10.1093/jiel/jgq037

[45] Vishwanath, T. and Kaufmann, D. (2001) Toward Transparency: New Approaches and Their Application to Financial Markets. World Bank Research Observer, 16, 41-57. https://doi.org/10.1093/wbro/16.1.41 